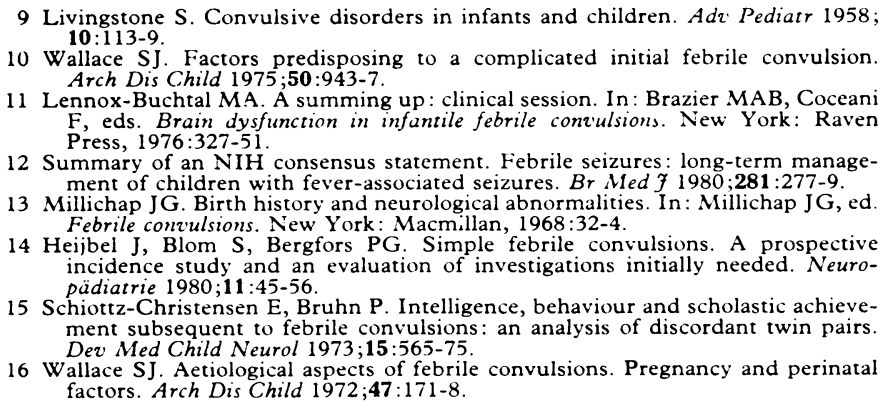

15 Schiottz-Christensen E, Bruhn P. Intelligence, behaviour and scholastic achievement subsequent to febrile convulsions: an analysis of discordant twin pairs. ment subsequent to febrile convulsions:

16 Wallace SJ. Aetiological aspects of febrile convulsions. Pregnancy and perinatal factors. Arch Dis Child 1972;47:171-8.

17 Ross EM, Peckham CS, W'est PB, Butler NR. Epilepsy in childhood: findings from the National Child Development Study. BrMed $\mathcal{F} 1980 ; 280: 207-10$.

Van den Berg BJ, Yerushalmy $J$. Studies on convulsive disorders in young children. I. Incidence of febrile and nonfebrile convulsions by age and other factors. Pediatr Res $1969 ; 3: 298-304$.

19 Friderichsen C, Melchior J. Febrile convulsions in children, their frequencr

20 Wallace S J. Febrile convulsions: their significance for later intellectual development and behaviour. $\mathcal{F}$ Child Psychol Psychiatry $1984 ; 25: 15-2$ allace $S$ J. Neurological and intellectual deficits: convulsions with fever viewed as acute indications of life-long developmental defects. In: Brazier M.AB, Coceani 1 , eds. Bruin dysfunc

22 Aldridge-Smith J, Wallace SJ Febrile convulsions: intellectual progress in relation to anti-convulsant therapy and to recurrence of fits. Arch Dis Child 1982;57:104-7.

(Accepted 28 fanuary 1985)

\title{
Effect of enterocoated cholestyramine on bowel habit after ileal resection: a double blind crossover study
}

\author{
OLI JACOBSEN, LISELOTTE HØJGAARD, ELLINOR HYLANDER MØLLER, \\ TORBEN O WIELANDT, MARGRETHE THALE, STIG JARNUM, EINAR KRAG
}

\begin{abstract}
Ileal resection causes malabsorption of bile acid; the increased load of bile acids in the colon induces increased secretion of salt and water and hence diarrhoea. A study was carried out to test the effect of an enterocoated cholestyramine tablet designed to disintegrate in the colon and sequester the bile acids there, thereby minimising diarrhoea induced by bile acids while having no effect on malabsorption of bile acid and jejunal fat absorption.
\end{abstract}

The study comprised 14 patients who had undergone ileal resection of $40-150 \mathrm{~cm}$ for Crohn's disease. A double blind crossover trial was performed with placebo and cholestyramine enterocoated with cellulose acetate phthalate. During treatment with cholestyramine the daily faecal output decreased, the number of defecations each week decreased, and the intestinal transit time increased. Acceptability of the tablets was high, in contrast with general clinical experience with cholestyramine powder. No change was observed in the total faecal output of bile acids or fat.

Cholestyramine tablets caused a reduction in diarrhoea without noticeably interfering with the metabolism of fat or bile acid.

Department of Gastroenterology P, Rigshopitalet, University of Copenhagen, Denmark

OLI JACOBSEN, MD, registrar

MARGRETHE THALE, MSC, biochemist

STIG JARNUM, MD, chief physician and senior lecturer

Division of Gastroenterology, Department of Internal Medicine,

Hvidovre Hospital, University of Copenhagen, Denmark

LISELOTTE HØJGAARD, MD, registrar

ELLINOR HYLANDER MØLLER, MD, senior registrar and lecturer

EINAR KRAG, MD, chief physician and senior lecturer

Central Hospital Pharmacy, Herlev

TORBEN O WIELANDT, MD, pharmacist

Correspondence to: Dr Liselotte Hoigaard, Department of Clinical Physiology and Nuclear Medicine 239, Hvidovre Hospital, DK-2650 Copenhagen.

\section{Introduction}

Some bile acids are absorbed passively in the proximal small intestine, but there is also an important active transport mechanism in the terminal ileum. ${ }^{\prime}$ : Patients with an ileal resection of $30 \mathrm{~cm}$ or more may develop malabsorption of bile acid, resulting in an increased passage of bile acids into the colon, where dihydroxy bile acid induces the secretion of salt and water and hence diarrhoea. ${ }^{3}$ Hitherto, conventional cholestyramine powder has been used with some success to sequester bile acid,': But such treatment has two physiological disadvantages. Firstly, the jejunal concentration of non-sequestered bile acids is below the optimum for sufficient solubilisation of the lipolytic products after meals and thus the result is malabsorption of fat, steatorrhoea, and diarrhoea induced by fatty acids. Secondly, malabsorption of bile acid is increased because sequestered bile acids are not available for small intestinal absorption. It might therefore be an advantage to ingest cholestyramine in a tablet that releases the active substance in the colon, thereby not influencing malabsorption of bile acid and fat. In vivo studies of patients who had not had operations and healthy volunteers suggested that cellulose acetate phthalate might be an ideal coating for cholestyramine tablets as the coating, and hence the tablet, disintegrated in the most distal part of the ileum, caecum, or ascending colon.

The aim of our study was to investigate the effect of cholestyramine tablets coated with cellulose acetate phthalate in patients with diarrhoea and malabsorption of bile acid caused by ileal resection.

\section{Patients and methods}

Eleven women and three men aged 27-66 (median 42) consented, in accordance with the Helsinki II declaration, to participate in the study, which was accepted by the local human studies committee. The patients had undergone ileal resection of $40-150 \mathrm{~cm}$ (median 65 $\mathrm{cm}$ ) because of Crohn's disease, but at least half of the colon had been preserved. The table gives clinical and laboratory data. The chronic inflammatory bowel disease was mild in all patients and did not change during the study. Five patients received sulphasalazine $3 \mathrm{~g}$ daily and two prednisone $2 \cdot 5-7 \cdot 5 \mathrm{mg}$ daily.

The study lasted three weeks: one week of treatment with cholestyramine tablets coated with cellulose acetate phthalate; one week of equilibrium (washout period); and one week of treatment with placebo tablets containing barium sulphate coated with cellulose acetate 
phthalate. A randomised double blind crossover design was used, allowing each patient to serve as his own control. Four tablets were ingested three times daily with meals, and two tablets were taken if snacks were eaten between meals. Patients were asked to record their consumption of tablets, attacks of pain, and an overall assessment of wellbeing. For the last three days of each week of treatment patients were admitted for collection of stools. All patients took a standardised diet that supplied $70 \mathrm{~g}$ fat/day.

\section{EXAMINATIONS AND ANALYSES}

The placebo tablets contained barium sulphate with the same coating as the cholestyramine tablets. On the last day of both treatments the positions and sites of disintegration of the tablets were examined fluoroscopically every 30 minutes from $8 \mathrm{am}$ to $4 \mathrm{pm}$ as described
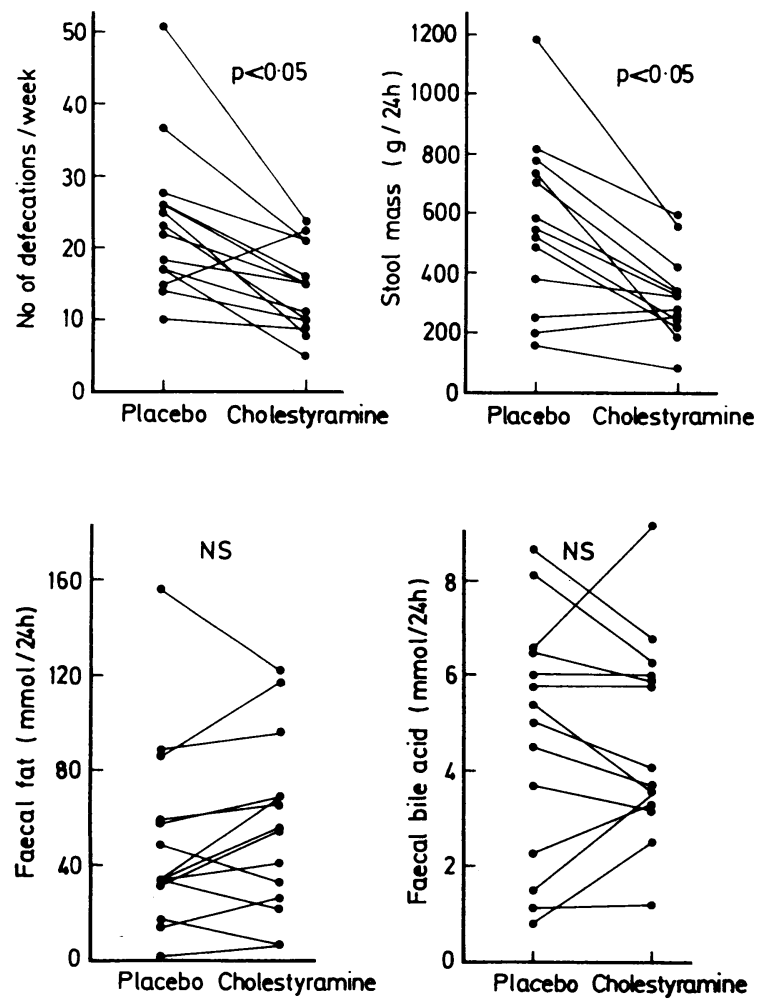

FIG 1-Effect of enterocoated cholestyramine on number of defecations, stool mass, and faecal output of fat and bile acids $(n=14)$.

previously. ${ }^{6}$ Placebo tablets were seen easily and the position of disintegration determined without difficulty. Disintegration of the coatings was assumed to take the same length of time whether the tablets contained the radiolucent cholestyramine or the radio-opaque barium sulphate. Patients were not allowed to see the screen, and the fluoroscopist did not take part in the trial because of his knowledge of the coding of the patients. Fluoroscopy was performed identically during both periods of treatment so that patients remained blinded, but during treatment with cholestyramine minimum radiation was used. The total exposure was less than two minutes-that is, less than $9 \mathrm{mGy}(0.9 \mathrm{rads})$ on a $15.2 \mathrm{~cm}$ abdominal field.

Intestinal transit time was determined by oral administration of 20 small radio-opaque plastic markers that were detected in stools on three consecutive days. ${ }^{\top}$ The transit time was expressed as the amount of marker recovered as a percentage of the amount ingested. Stool mass was expressed as the mean output on three consecutive days (reference value $<200 \mathrm{~g} /$ day). Faecal fat was determined by a standard method (reference value $<25 \mathrm{mmol} /$ day). ${ }^{8}$ Total faecal bile acids were determined enzymatically by the $3 \alpha$-steroid dehydrogenase method (reference range $0-975 \mu \mathrm{mol} /$ day). ${ }^{9}$ This technique, however, excludes bile acids that are bound to cholestyramine. Analyses of calcium and magnesium in stools were carried out by atomic absorption spectrophotometry (Varian Techron, model AA-6). ${ }^{10}$ Faecal sodium and potassium were measured by flame photometry. Haemoglobin con- centrations, B lymphocytes, and plasma concentrations of albumin, creatinine, cholesterol, and triglycerides were determined by standard methods used at our university.

The active tablets contained compressed granules of cholestyramine (Cuemid 0.5 g; Merck, Sharp and Dohme, United States of America) with an enterosoluble coating made of cellulose acetate phthalate, ${ }^{11}$ castor oil, ${ }^{12}$ and acetone. ${ }^{13}$ The coating was sprayed over the cores of the tablets in a kettle to provide an in vitro disintegration time of 10 minutes at $\mathrm{pH} 7 \cdot 2$ when measured by standard methods. ${ }^{14}$ This disintegration time was chosen after a preliminary study of 15 patients showed that coated tablets disintegrated in the jejunum, caecum, and left colon at five, 10, and 15 minutes, respectively.

The rank sum test for paired differences was used for statistical analysis.

\section{Results}

\section{DISINTEGRATION OF THE TABLETS}

The tablets disintegrated in the most distal part of the remaining ileum or caecum or, in patients who had had a partial colon resection, at the anastomosis between the ileum and ascending or transverse colon. In three patients disintegration did not occur within eight hours
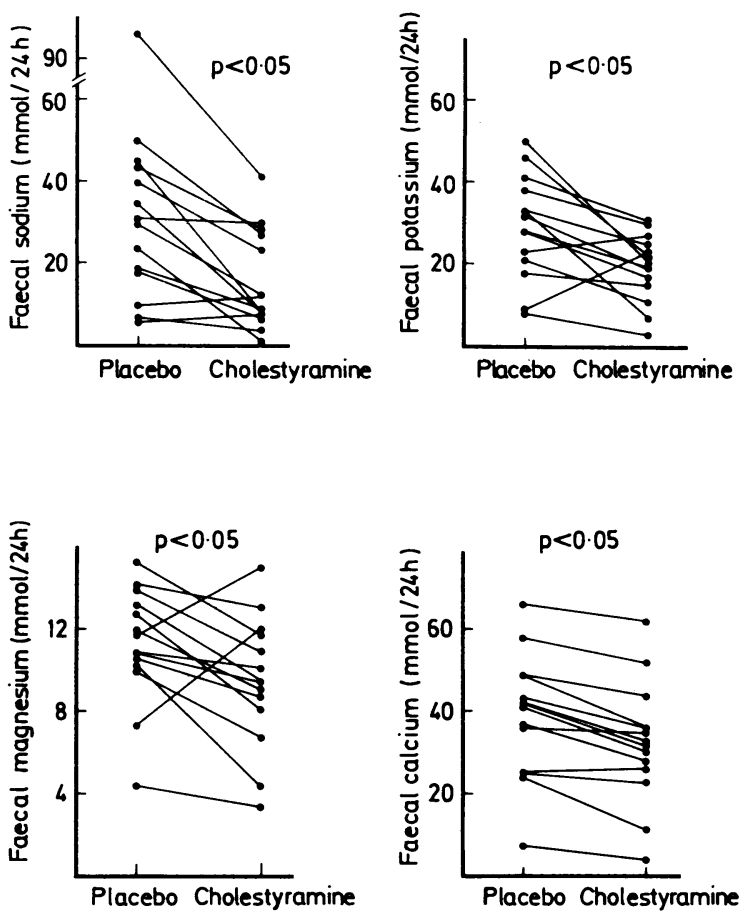

FIG 2-Effect of enterocoated cholestyramine on faecal output of sodium, potassium, magnesium, and calcium $(n=14)$.

Conversion: SI to traditional units-Sodium: $1 \mathrm{mmol} / 24 \mathrm{~h}=$ $1 \mathrm{mEq} / 24 \mathrm{~h}$. Potassium : $1 \mathrm{mmol} / 24 \mathrm{~h}=1 \mathrm{mEq} / 24 \mathrm{~h}$. Magnesium: $1 \mathrm{mmol} / 24 \mathrm{~h}=24 \cdot 31 \mathrm{mg} / 24 \mathrm{~h}$. Calcium: $1 \mathrm{mmol} / 24 \mathrm{~h}=40 \mathrm{mg}$ ! $24 \mathrm{~h}$.

after ingestion; for practical reasons fluoroscopy was not performed after this time. The tablets in these patients were last seen in the duodenum or jejunum. Disintegration took place in the sigmoid colon in one patient and in the jejunum in another. No problems were observed if the tablets disintegrated somewhere other than in the colon. Thus in five of the 14 patients the tablets did not disintegrate in the desired place. It cannot be excluded, therefore, that the mechanism of action of cholestyramine is independent of the theoretical model of absorption of bile acid.

\section{STOOL VARIABLES}

Of the 14 patients, 13 recorded a decrease in the number of defecations. The median number of bowel movements decreased from 23 to 15 per week-that is, by $35 \%(p<0.05)$ (fig 1$)$. In one patient 
who had an increased number of evacuations the stool volume decreased from 380 to $323 \mathrm{~g} / 24 \mathrm{~h}$. Cholestyramine reduced the median stool mass from $566 \mathrm{~g}$ to $313 \mathrm{~g} / 24 \mathrm{~h}(\mathrm{p}<0.05)$-that is, by $45^{\circ}{ }_{\mathrm{o}}$ (fig $\mathrm{l}$ ). All patients with a normal stool frequency had an abnormal stool mass, and all showed a decrease in stool mass during treatment. In one patient, in whom the tablets were undissolved in the duodenum after eight hours, stool mass increased from 252 to $279 \mathrm{~g} / 24 \mathrm{~h}$. In another, in whom the tablets disintegrated in the sigmoid colon, stool mass increased from 195 to $277 \mathrm{~g} / 24 \mathrm{~h}$. In all patients faecal output of fat and bile acids showed no significant change (fig 1).

During treatment with cholestyramine compared with placebo faecal excretion of electrolytes decreased: median sodium values were 30 and $11 \mathrm{mmol}(\mathrm{mEq}) / 24 \mathrm{~h}(\mathrm{p}<0.05)$; potassium 30 and $19 \mathrm{mmol}$

\section{Discussion}

Our results show that cholestyramine coated with cellulose acetate phthalate was effective in reducing faecal mass and the number of defecations in patients with moderate ileal resection and mild steatorrhoea without changing faecal excretion of bile acid and fat. These results agree largely with those of a study of cholestyramine powder, in which faecal mass and faecal excretion of sodium and potassium were reduced. The advantage of the tablets is that the usual increase in faecal excretion of bile acid and fat is avoided. In the two patients in our study with an ileal resection of more than $100 \mathrm{~cm}$ faecal mass was decreased by

Clinical and laboratory data on patients studied

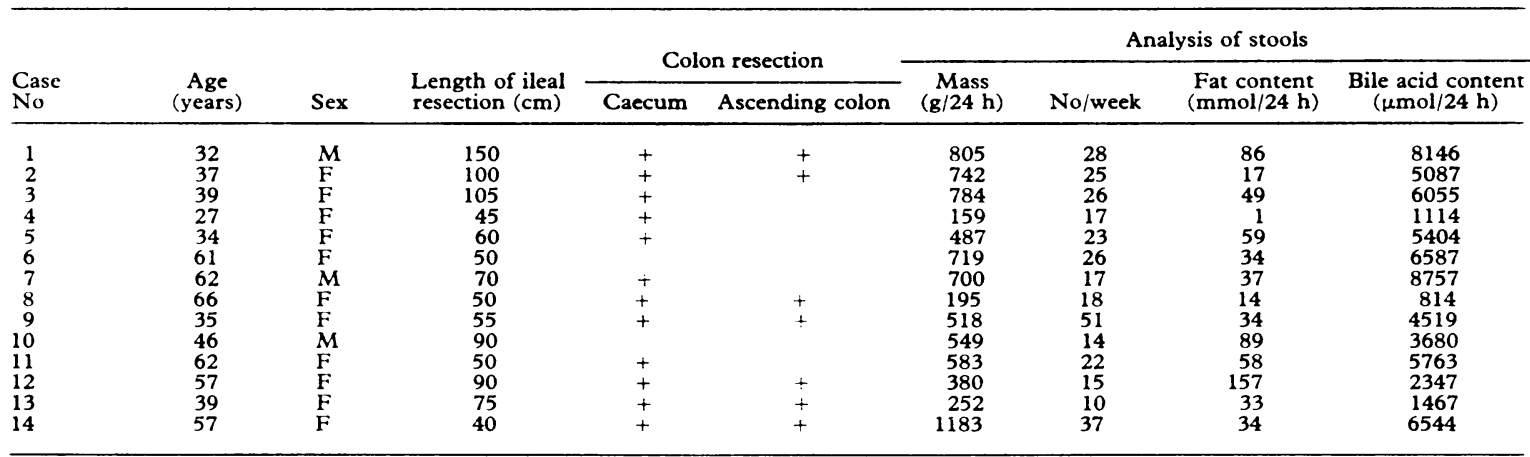

$(\mathrm{mEq}) / 24 \mathrm{~h}(\mathrm{p}<0.05)$; magnesium 11.3 and $9.5 \mathrm{mmol} / 24 \mathrm{~h}(275$ and $231 \mathrm{mg} / 24 \mathrm{~h})(\mathrm{p}<0.05)$; and calcium 42 and $33 \mathrm{mmol} / 24 \mathrm{~h}(1683$ and $1323 \mathrm{mg} / 24 \mathrm{~h})(\mathrm{p}<0.05)$ (fig 2). All blood values, including serum lipid concentrations, were unchanged.

The median transit time was increased by $7 \%(p<0.05)$ during treatment with cholestyramine compared with placebo (fig 3). In two patients measurement of transit time failed because the markers were not ingested. The order of treatment did not affect the changes in any of the variables studied.

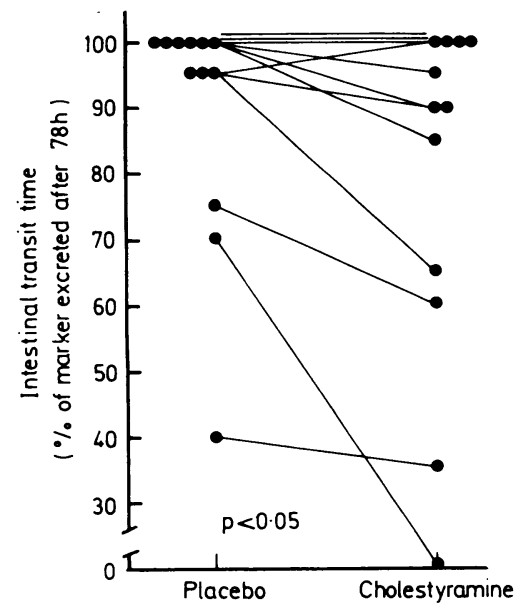

FIG 3-Effect of enterocoated cholestyramine on intestinal transit time $(n=12)$.

In seven patients the ascending colon had been preserved, and in another seven it had been resected (table). No significant difference was seen between these two groups of patients with respect to the reduction in faecal mass or pattern of faecal excretion of bile acid, fat, sodium, potassium, or calcium during treatment with cholestyramine, but faecal excretion of magnesium was significantly lower in patients in whom the ascending colon had been preserved.
$26 \%$ and $32 \%$; this contrasts with previous reports showing no effect of cholestyramine powder on faecal mass in such patients. ${ }^{5}$

We found a significant decrease in faecal excretion of calcium, which suggests that enterocoated cholestyramine might reduce the malabsorption of calcium seen in patients with resection of the small bowel. ${ }^{15}$ Previous reports have shown excretion of calcium to be unchanged during treatment with cholestyramine powder. ${ }^{5}$

The ascending colon is considered to be the major site of absorption of salt and water in the colon, and in a previous study all patients who responded to cholestyramine had some ascending colon remaining. ${ }^{16}$ In our study, however, no significant differences in faecal variables were seen between the patients with and without preserved ascending colon. This indicates that the presence of the ascending colon is not essential for enterocoated cholestyramine to have a beneficial effect. This agrees with a report of treatment with cholestyramine in a patient with an ileal resection of $75 \mathrm{~cm}$ and an ileotransversostomy. ${ }^{17}$

Compliance of patients with treatment with cholestyramine given as a powder is low because of the drug's bad taste, but in our study compliance and acceptability were high. The daily dose of cholestyramine was $6 \mathrm{~g}$ daily (12 tablets). The tablets were palatable and the enterocoating smooth. None of the patients recorded side effects or difficulties in taking the tablets. We therefore suggest that such tablets should be available in the treatment of patients with diarrhoea due to ileal resection. Negotiations are taking place with a drug company that may be willing to produce these tablets on a non-profit basis.

This study was supported by the King Christian X Foundation, the Foundation for Advancement of Medical Science, and the P Carl Petersen Foundation.

\section{References}

1 Hofmann AF. The enterohepatic circulation of bile acids in man. Clin Gastroenterol $1969 ; 6: 397-403$.

$2 \mathrm{Krag}$ E, Phillips SF. Active and passive bile acid absorption in man. $\mathcal{f}$ Clin Invest

3 Hofmann AF. Bile acid malabsorption caused by ileal resection. Arch Intern Med 1972;130:597-605. 
4 Hofmann AF, Poley JR. Cholestyramine treatment of diarrhoea associated with ileal resection. N Engl f Med 1969;281:397-402.

5 Hofmann AF, Poley JR. Role of bile acid malabsorption in pathogenesis of diarrhoea and steatorrhoea in patients with ileal resection. I. Response to cholestyramine or replacement of dietary long chain
glyceride. Gastroenterology $1972 ; 62: 918-34$.

6 Dragsted L, Boesen E, Wielandt TO, Krag E. Celluloseacetatftalatovertrukne tabletters henfald pà forudbestemt sted i tarmen. Ugeskr Laeger 1979;141:132730 .

7 Hinton JM, Lennard-Jones JE, Yong AC. A new method for studying gut transit times using radioopaque markers. Gut 1969;10:842-7.

8 Van de Kamer, Huining HTB, Weyers HAJ. Rapid method for the determination of fat in faeces. $\mathcal{F}$ Biol Chem 1949;177:347-55.

9 Malchow-Moller A, Arffmann S, LaRusso NF, Krag E. Enzymatic determination of total $3 x$-hydroxy bile acids in faeces. Scand $\mathcal{f}$ Gastroenterol 1982;17:331-3.

10 Ladefoged $\mathrm{K}$, Nicolaidos $\mathrm{P}$, Jarnum $\mathrm{S}$. Calcium, phosphorus, magnesium, zinc, and nitrogen balance in patients with severe short bowel syndrome. Am $\mathcal{F}$ Clin
Nutr $1980 ; 33: 2127-44$.

11 United States Pharmacopeial Convention. Cellulose acetate phathalate. United
States Pharmacopeia (official monograph). 15th ed. New York: Board of Trustees of United States Pharmacopeial Convention, 1980:1219.

12 United States Pharmacopeial Convention. Aromatic castor oil. United States Pharmacopeia (official monograph). 20th ed. New York: Board of Trustees of United States Pharmacopeial Convention, 1980:15-6.

13 United States Pharmacopeial Convention. Acetone. United States Pharmacopeia (official monograph). 20th ed. New York: Board of Trustees of United States Pharmacopeial Convention, 1980:15-6.

14 United States Pharmacopeial Convention. Disintegration. Physical tests. United States Pharmacopeia (official monograph). 20th ed. New York: Board of Trustees of United States Pharmacopeial Convention, 1980:701-958.

15 Hylander Moller E, Ladefoged K, Jarnum S. The importance of the colon in calcium absorption following small intestinal resection. Scand f Gastroenterol

16 Levitan R, Fordtran JS, Burrows BA, Ingelfinger FJ. Water and salt absorption in human colon. $\mathcal{F}$ Clin Invest $1962 ; 41: 1754-9$.

Gastroenterology 1967;53:1006.

(Accepted 28 fanuary 1985)

\section{SHORT REPORTS}

\section{Hyperphosphataemic rickets in an Asian infant}

We have recently shown that hyperphosphataemic rickets is associated with hyporesponsiveness of renal tubules to parathyroid hormone. Patients with this disorder have extremely low basal excretions of phosphate in their urine; urinary phosphate and cyclic adenosine monophosphate increase only marginally after challenge with parathyroid hormone. ${ }^{1}$ After treatment with vitamin $\mathrm{D}$ plasma phosphate concentration becomes normal and urinary phosphate excretion increases.' This hyperphosphataemic variant of rickets has hitherto not been described in an infant. We describe one such infant with severe deficiency of vitamin D. So far as we know this is the first reported case of hyperphosphataemic rickets in an infant.

\section{Case history}

A baby boy was born to healthy unrelated Asian parents after a full term, non-eventful pregnancy. Both parents were vegetarian and the mother had received only folic acid and iron supplements during her pregnancy. The infant was breast fed. At 13 days of age he developed projectile vomiting and shortly after admission to hospital he had a twitching episode lasting four minutes. Results of investigations were: plasma calcium concentration $1.26 \mathrm{mmol} / 1(5.0 \mathrm{mg} / 100 \mathrm{ml})$; phosphate concentration $2.8 \mathrm{mmol} / 1(8.7 \mathrm{mg}$ i $100 \mathrm{ml}$ ); alkaline phosphatase activity $361 \mathrm{IU} / 1$; magnesium concentration $0.57 \mathrm{mmol} / \mathrm{l}(1.4 \mathrm{mg} / 100 \mathrm{ml})$; glucose concentration $3.0 \mathrm{mmol} / \mathrm{l}(54 \mathrm{mg}$ ! $100 \mathrm{ml}$ ). 25-Hydroxyvitamin $\mathrm{D}$ was undetectable in serum samples from the baby and the mother. He recovered after intravenous and oral calcium supplements and intramuscular magnesium sulphate and was discharged from hospital six days later taking multivitamin drops (Abidec) $0.6 \mathrm{ml}$ twice daily ( $800 \mathrm{IU}$ daily).

The patient was readmitted six days later (age 28 days) with a recurrence of twitching. Plasma calcium concentration was $1.56 \mathrm{mmol} / \mathrm{l}(6.2 \mathrm{mg}$. $100 \mathrm{ml})$ and phosphate concentration $2.9 \mathrm{mmol} / 1(9.0 \mathrm{mg} / 100 \mathrm{ml})$. Oral calcium supplements and alfacalcidol $1.25 \mu \mathrm{g}$ twice daily were begun. Three generalised grand mal convulsions then necessitated a further admission (age 40 days). Plasma calcium concentration was $1.76 \mathrm{mmol} / 1(7.0 \mathrm{mg}$ $100 \mathrm{ml}$ ) and alkaline phosphatase activity $268 \mathrm{IU} / \mathrm{l}$. He was treated with oral calcium supplements and phenobarbitone. Electroencephalography, radiography of skull, cranial ultrasound examination, and metabolic and infection screens all gave negative results. The parathyroid hormone concentration on day 52 was raised at $86 \mathrm{pmol} / 1(8.6 \mathrm{pg} / \mathrm{ml})$. He was discharged from hospital (age 57 days) taking alfacalcidol $1 \mu \mathrm{g}$ twice daily and multivitamin drops $1.2 \mathrm{ml}$ daily. Plasma calcium concentration rose to $2.05 \mathrm{mmol} / \mathrm{l}$ $(8.2 \mathrm{mg} / 100 \mathrm{ml})$, phosphate was $2.84 \mathrm{mmol} / 1(8.8 \mathrm{mg} / 100 \mathrm{ml})$, and alkaline phosphatase activity was $343 \mathrm{IU} / 1$. Alfacalcidol was discontinued at 108 days of age. At 6 months he was thriving and taking no medication. Calcium concentration was $2.4 \mathrm{mmol} / 1(9.6 \mathrm{mg} / 100 \mathrm{ml})$, phosphate $2.2 \mathrm{mmol} / \mathrm{l}$ $(6.8 \mathrm{mg} / 100 \mathrm{ml})$, alkaline phosphatase activity $360 \mathrm{IU} / \mathrm{l}$, and parathyroid hormone concentration $36 \mathrm{pmol} / \mathrm{l}(3.6 \mathrm{pg} / \mathrm{ml})$. A chest radiograph on day 40 was reported as normal but on retrospective examination showed severe splaying and rarefaction of the anterior ends of the ribs.

\section{Comment}

This infant's biochemical abnormalities were accounted for by severe vitamin D deficiency: the features were low calcium concentration; raised alkaline phosphatase activity; non-detectable 25-hydroxyvitamin $\mathrm{D}$ in both the infant and the mother; raised

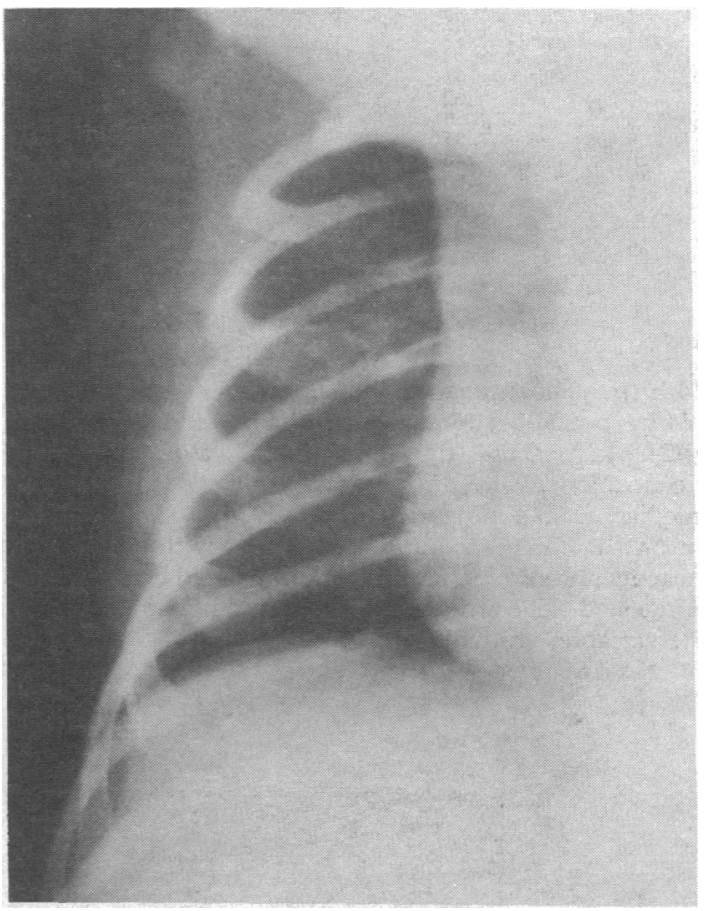

Chest $x$ ray appearances on day 40 showing splaying and rarefaction of anterior ends of ribs.

parathyroid hormone concentration; and, finally, response to an antirachitic dose of vitamin D in multivitamin drops, which increased his calcium concentration from 1.26 to $1.76 \mathrm{mmol} / 1(5.0$ to $7.0 \mathrm{mg}$ / $100 \mathrm{ml}$ ) before the introduction of alfacalcidol. Such a dose of vitamin $\mathrm{D}$ is unable to raise the plasma calcium value in patients with hypoparathyroidism and pseudohyperparathyroidism. The only unusual biochemical feature in this patient was the greatly increased plasma phosphate concentration, which initially led to considerable confusion about the diagnosis. It was only in retrospect that we arrived at the diagnosis of "hyperphosphataemic rickets." Review of the chest radiograph at that time showed severe splaying and rarefaction of the anterior ends of the ribs. These changes could have heralded the formation of a rachitic rosary. Hyperphosphataemia in association with rickets has recently been shown by us to be due to severe vitamin $\mathrm{D}$ deficiency and a severely diminished end organ (especially renal tubular) response to parathyroid hormone. ${ }^{1}$ These patients require large doses of vitamin $\mathrm{D}$, at least initially, since their vitamin $D$ reserves are totally depleted.

These data emphasise that hypovitaminosis $\mathrm{D}$ is the commonest cause of hypocalcaemia in Asian neonates. ${ }^{2}$. Thus even in the presence of the unusual feature of a raised plasma phosphate concentration, vitamin $\mathrm{D}$ deficiency must be considered as the primary cause of hypocalcaemia. 